\title{
Haemostaxis
}

\section{Fundamental Mechanisms Involved in Thrombosis and Haemostasis}

In the end, all progress in thrombosis prevention and treatment will stem from a better understanding of the fundamental mechanisms involved. 'It is some light in some laboratory that some day will make the difference'. But the road to that end may be deceivingly curved and the day discouragingly far. In the 50s, when clotting physiology was hardly biochemically based, much was expected from the application of protein chemistry and enzymology. Now we know the structure and most of the functions of all the clotting factors and it seems as if the patient hardly profits. In the 70s the hopes were high as to the possible impact of molecular biology. Now we see that it certainly helps, but again, it is not an easy short circuit to the solution of the problems that our patients pose. Neither has the cell biology of the platelet led to a magic bullet.

If our intuition does not betray us, the word is now to 'supra-molecular' biology, i.e. to the study of ever larger sub-systems of the haemostatic-thrombotic mechanism, so as to better understand the regulation of this mechanism in real life. Those of you that think that this is pretty near to old fashioned chemical physiology are probably right, but this time it is chemical physiology with all the knowledge of details that have been brought by the arduous work of precisely those protein chemists, enzymologists, cell biologists and molecular biologists that we alluded to above.

The only thing that we may really be sure of is that the problem that we posed ourselves is much more complex than we dared to imagine in the beginning. Therefore, it is useful that, from time to time, those who have experience in the field take the pains to separate the wheat from the chaff and give an overview of the essentials in their domain.

A number of reputed scientists has accepted to do so at the occasion of the 15th International Congress on Thrombosis organised in September 1998 in Antalya, by Prof. Orhan Ulutin, for the Mediterranean League against Thrombosis and the Thrombosis Society of Turkey. We are very grateful to Prof. Ulutin and the Thrombosis Society of Turkey for allowing us to publish these state-of-theart lectures here, also on behalf of our readers that can now find this information in the peerreviewed literature.

\author{
S. Lévy-Toledano, Paris \\ H.C. Hemker, Maastricht
}

\begin{tabular}{ll}
\hline KARGER & ( 1999 S. Karger AG, Basel \\
Fax +4161306 1234 & \\
$\begin{array}{l}\text { E-Mail karger@karger.ch } \\
\text { www.karger.com }\end{array}$ & $\begin{array}{l}\text { Accessible online at: } \\
\text { http://BioMedNet.com/karger }\end{array}$
\end{tabular}

